\title{
CONTEMPORARY ISSUES IN ART: THE ONLINE CLASS
}

\author{
Elluminate gave me confidence to explore new teaching strategies. That may have been the most \\ important outcome of the whole experience.
}

Anne Jeffrey, Adjunct Professor of Art History at the University of South Florida (USF), reflected on her experiences of the past semester teaching ARH-3475, Contemporary Issues in Art. In late September of 2005, she had delivered what was - for her and her students - a new type of class. Using Elluminate, an online synchronous classroom technology, she had conducted the entire class online. Doing so had allowed her to include not only students in the class, but also guests that included a museum curator and several artists whose work was being exhibited as part of the "Florida Focus: Northern Tropics" exhibition at the Gulf Coast Museum of Art in Largo, Florida. The highly positive outcome of that online session had emboldened her to incorporate more field trips and other outside activities into the balance of the semester's schedule. Enthusiastic student responses had suggested that her new course design had led to one of her most successful teaching efforts to date.

As the semester drew to a close, she wondered if she could repeat the experience in future classes, or if it had been a fluke. Indeed, she had concerns in numerous areas. These included:

- Technology: Highly experienced users had cautioned her that the online classroom would not always function as smoothly as it had for her September session. What would she do if serious technical issues emerged during a session?

- Participant personalities: One aspect of the online session that had caused he great anxiety had been her lack of control over the participants—students, artists and administrators. The artistic community had more than its fair share of "personalities". What would she do if one or more guests refused to talk or, perhaps even worse, refused to stop talking?

- Priorities: Setting up the class had taken huge amounts of time on her part. ARC-3475 was just one of 6 sections of 4 different courses she was teaching that semester. Could she afford to devote

This case was prepared for the purpose of class discussion, and not to illustrate the effective or ineffective handling of an administrative or classroom situation and is copyrighted by the Informing Science Institute. Permission to make digital or paper copy of part or all of these works for personal or classroom use is granted without fee provided that the copies are not made or distributed for profit or commercial advantage AND that copies 1) bear this notice in full and 2) give the full citation on the first page. It is permissible to abstract these works so long as credit is given. To copy in all other cases or to republish or to post on a server or to redistribute to lists requires specific permission and payment of a fee. Contact Publisher@InformingScience.org to request redistribution permission. so much time to it in the future?

- Fairness: In the spring, she'd be teaching two sections of the courseone being a night class at a different USF campus. In the past, she'd always ensured that all sections had the same educational experience. Would it be fair to offer the online session to one section, but not the other? 


\section{Anne Jeffrey}

Anne Jeffrey, profiled in Exhibit 1, came to academia rather late in life. She described her early activities as follows:

After completing my BA in Modern History at the $\mathrm{U}$ of $\mathrm{T}$ in 1966, I researched and composed the texts for the Province of Ontario's historical marker program. Subsequently, marriage and motherhood allowed me to pursue writing of a less lucrative nature: plays for live theatre. My work has been produced by CBC Canada and in San Diego California. For not altogether solid reasons, I moved into the wilderness of northern British Columbia in 1978 where I lived for almost 20 years. During that time, I started a small business in communications training and taught on native reservations. What this all proves, I suppose, is that I'm not averse to risk taking in my career endeavors.

Jeffrey completed a Master's degree in Art History at USF in 2001, after which she joined the faculty as an Adjunct Professor. In this capacity, she was given a substantial teaching load. In the fall of 2005, for example, she was assigned to teach 4 different undergraduate courses: two web-based sections of ARH3001 (Introduction to Art) with combined enrollments of 571 students, two telecourse sections--lectures broadcast over the USF television station — of ARH-4930 (Art in the Western World) with combined enrollments of 27 students, one section of ARH-4450 (20 ${ }^{\text {th }}$ Century Art $)$ offered at USF's St. Petersburg campus with 26 students enrolled and one section of ARH-3475 (Contemporary Issues in Art) offered at USF's main campus in Tampa with 33 students enrolled.

Although she did not view herself as a technologist, by any means, Jeffrey was intrigued by the possibility of enhancing the effectiveness of her courses by any means possible. As a consequence, when she was offered the opportunity to participate in the Increments and Transformations Institute (ITI), offered by USF's Center for $21^{\text {st }}$ Century Teaching Excellence $\left(C^{21} \mathrm{TE}\right)$, she jumped at the chance. In the course of attending the ITI's 2005 summer workshop, she was exposed to many technologies and concepts that seemed potentially relevant to her classes. Of particular interest, she felt, was Elluminate-a technology that allowed the instructor to set up a virtual classroom or office. During the workshop, she had participated in several online discussions and presentations that employed the tool in a variety of ways: to discuss cases, to demonstrate technologies, and simply to allow participants to meet each other. Given the types of classes she was going to be teaching in the fall, she felt the tool might fit her needs very well.

\section{Elluminate}

Elluminate was a sophisticated web-based classroom/conferencing tool that USF was making available to faculty members at the time of the case. As illustrated in Exhibit 2, the tool's visual interface centered around two key features:

- A shared whiteboard. Complete or partial control of the board could be given to participants, which could be used for drawing or typing, and could also be used to display PowerPoint slides or run multimedia presentations.

- Half-duplex audio chat. Participants could broadcast their voice to all other participants, provided they had a microphone. The half-duplex aspect of the technology (similar to a walkie-talkie or CB-radio) meant that — unlike a telephone or voice-over-the-Internet protocols (VoIP)—only one participant could speak at a time. Broadcast access was controlled by a "Talk" button (see Exhibit 2) that was disabled when someone else was speaking. 
Elluminate offered a number of additional features that made it particularly suitable for educational purposes. These included:

- Text chat: Text based chat, operating in parallel with voice chat, could also be used by participants-particularly those lacking access to microphones.

- Private breakout rooms: Virtual offices could be established at will. Participants in these offices could interact with each other without interfering with activities going on in the main room or other breakout rooms. Using these rooms made conducting group exercises during a class straightforward.

- $\quad$ Online quizzes and surveys: Tests and surveys could be defined in advance and administered to participants. Results could be kept private (limited to the instructor) or displayed to participants.

- Guided Web tours: The instructor could specify a web site and then all participants would see the web site appear in their own browsers. This allowed web sites to be explored in the context of a class without losing control.

- Application sharing: Applications could be launched on one system and then viewed — or even controlled, if so specified by the instructor-on all other systems. This permitted software to be demonstrated and tutorials to be offered. It could even be used to assist students during office hours (e.g., they could open a document or application file on their own system and share it with the instructor, who could then discuss it).

- Session recording: Sessions could be recorded for later viewing by students, allowing missed sessions to be made up and complex material presented in a session to be reviewed.

In addition to its extensive feature set, Elluminate was also designed so that it could support users with less than ideal connections. For example, the technology assigned different priorities to different types of content - with voice communications having the highest priority. It would also spool content that could not be transmitted immediately (similar to the way a network printer manages print jobs). As a result, if a user's connection were interrupted for a few seconds, he or she would still end up hearing all the audio content; there would just be a slight delay until the system caught up. The practical implication of this was that users coming in on a dialup connection generally experienced adequate performance, particularly if high-bandwidth features (such as application sharing) were not being used in parallel with the audio content.

In 2005, USF had contracted with Elluminate to allow for a full scale trial of the product. Under the terms of the license, faculty members were given almost unlimited access to the product (with actual hosting and technical support supplied by the vendor). Instructors were strongly encouraged to take advantage of the technology during the trial period, so that the university could assess whether the benefits were worth the high costs of acquiring a permanent license (estimated to be in the seven figure range).

\section{ARH-3475: Contemporary Issues in Art}

Jeffrey was particularly attracted to the idea of using Elluminate in her Contemporary Issues in Art (ARH-3475) class, an undergraduate capstone course for art majors taken at or near the end of their program. Specifically, she had seen guest faculty join the online sessions during the summer ITI workshop. Could this capability be employed to bring her students together with professional artists and art administrators?

For several reasons, ARH-3475 seemed a particularly good fit for such an experiment. First, since the course was given near the end of the student's program, she could expect students to be more 
knowledgeable and, hopefully, more mature. Second, since the course focused on contemporary art, the artists would, for the most part, be living - unlike French impressionists. Third, she had contacts, including former USF alumni, in some local galleries and museums. Finally, the course was constructed to emphasize class discussion and presentations, representing almost $50 \%$ of each student's grade (see Exhibit 3).

The nature of the course also carried some risk, however. Prominently placed in the syllabus (see Exhibit 3) was a warning:

Often you will view reproductions of work, in print, slide, DVD or video format which are considered by some people to be controversial due to the subject matter, materials and the real or perceived content.

The images shown in class will always be framed within the context of this course, i.e. the image is shown as a tool for understanding issues and current art practices. The image shown, in other words, is meant to demonstrate an issue under discussion --- such as censorship, for instance.

Images are not being presented as a form of titillation or as a spectacle for sensationalism. If you think you will not be comfortable viewing and discussing images of this nature (sometimes involving functions and activities of the human body), due to religious convictions and/or personal belief system it is recommended that you do not remain enrolled in this course.

Depending on the nature of the content being presented, she had concerns that students might react in unexpected ways. In the classroom, she was prepared to deal with that. Online, with the artist present, was a different matter.

Fortunately, one of the venues that had presented itself to Jeffrey offered a nice balance between the content and risk. In Largo, Florida—about an hour away from USF's main campus—-the Gulf Coast Museum of Art was holding a exhibition titled "Florida Focus: Northern Tropics", featuring art from the Florida panhandle (a thin strip at the northern boundary of the state located several hundred miles north and west of Tampa). Although some of the art was edgy (e.g., one George Blakely piece, titled "SelfPortrait with Bones", featured a photo of the naked artist lying down covered by a variety of animal bones), most reflected artistic impressions of the Florida flora and terrain. To add to the attractiveness of the site, the curator was a USF alumna and a number of artists had expressed interest in the online project.

\section{Online Class Day}

In recalling the events of the online class day, Jeffrey grouped them into three phases: the preparation, the online session, and the aftermath.

\section{Preparation}

As Jeffrey had expected, preparing for the online class session had been demanding. What was unexpected was the source of the demands. Certain aspects of the arranging the class, such as finding an appropriate venue and guests, had fallen into place with far less effort than she had anticipated. The more mundane aspects of the arrangements, however, had taken far more time than expected.

One challenge she had quickly run into was that of student equipment. For example, not every student had a computer or a reasonable Internet connection. While USF had plenty of computers available for student use (e.g., in labs and the library), using these computers presented three disadvantages. First, students had 
to reload the Elluminate software (a 10-15 minute process) each time they used the computer-since the university computers automatically erased all student installed software each time they were shut down, for reasons of security. Second, using these computers meant that students were talking in areas normally reserved for quiet activities. Finally, students would typically find themselves using different computers for practice sessions and online sessions - since computer availability was on a first-come, first-served basis. That meant that even if they successfully logged in during a practice session, there was no guarantee that things would proceed as smoothly during the actual session.

Availability of microphones presented another problem. Many students did not have there own computer microphones, and seemed reluctant to make the $\$ 10-\$ 20$ purchase for a single class day. Also, experienced Elluminate users had told Jeffrey that problems with microphones were-by far-the most common problem encountered with the technology. The fact that her class had so many novice microphone users-Jeffrey included herself in this category—was therefore cause for concern.

In an attempt to minimize the impact of these issues, during the class session that took place a week prior to the online class Jeffrey arranged to have a faculty colleague come into her class for half an hour to demonstrate the use of Elluminate. Her confidence in the project was further eroded when he reported that the system software could not be installed on the classroom computer. (He then went on to jury rig the demonstration using his laptop, changing a whole variety of podium connections that she'd never seen before).

As the class day drew closer, more concerns presented themselves. Although she had asked her students to test their connections during one or more practice sessions during the week, less than $20 \%$ of the class ended up doing so. As she tried to preload images of exhibit photographs on the Elluminate whiteboard, she ran into obstacles getting them to size properly. Perhaps worst of all, trying to arrange car-pooled transportation for the students from their homes to the exhibit after the online session proved to be a logistical nightmare. Not only did it involve planning complex routes through the city to get to student homes, she was also continually being frustrated by students who changed where they planned to be during the session. By the morning of the session, Jeffrey had many doubts that the class would actually come off. She was virtually certain, however, that she would never again be so foolish as to initiate such a project.

\section{Online Session}

In stark contrast to the preparations, so many things seemed to go so well with the session itself that Jeffrey could barely contain her excitement. First, the four outside guests—the Largo-based museum curator, the exhibition's guest curator connecting from Palm Beach, and the two artists, connecting from Northern Florida — had all managed to find the site and get their microphones working (although the two artists had to share a microphone). Second, nearly all the students managed to connect, with only minor technical problems. Third, the art had loaded properly (see Exhibit 4). Fourth, the presentations by the guests had been engaging and had left sufficient time for discussion. Fifth, the students had actually engaged in discussion.

The last of these aspects of the session had been, perhaps, her greatest source of relief. To ensure that there was no "dead air" time during the session, she had primed the students with possible questions they might ask and had emphasized that asking questions was a requirement, not an optional activity. To her surprise, students quickly departed from her suggested list of questions and began interacting with the guests in a genuine manner, asking probing questions relating to the nature of their art and the challenges facing individuals seeking a career in the arts. The resulting discussion delighted both students and guests, 
and post-session feedback (gathered in the subsequent class) was uniformly positive (see Exhibit 5 for examples of the comments).

In looking back at the session, Jeffrey decided that there were only a few things she would have changed. She decided that more artwork examples would have been beneficial, since students enjoyed commenting on these and - even when unrelated topics, such as art careers, were being discussed-moving from example to example on the whiteboard provided an engaging background. Somewhat surprisingly, the relatively low resolution of the graphic images that were uploaded did not seem to detract from the discussion. Much more significantly, she felt that she would have made the session longer. Neither the students nor the guests had run out of things to say when the 90 minute session had to end (in order to allow enough time for car-pooling to the museum to view the exhibit). She had expected to see more evidence of fatigue. Instead, what she observed was continuing enthusiasm and interest-far greater than what would be typical for a classroom discussion.

\section{Aftermath}

Once the online session had concluded, and a few more last-minute logistical changes had been arranged, the class had proceeded to the museum in Largo, where the highly successful day continued. Indeed, perhaps the most exciting aspect of the entire experiment was the way in which participating in the online session enhanced the museum visit. Normally students would visit a show "cold". Unfortunately, that meant that the process of building engagement with what they were seeing never got a chance to flourish. Coming to the museum after the online session, on the other hand, they walked in the door already eager to compare the reality of the work with the images they had previewed online. This, thought Jeffrey, was active learning at its best.

By the end of the day, Jeffrey was convinced that the session-visit experience had produced an extraordinary amount of student learning-learning of a type that would stay with them for years to come, and not dissipate immediately after the next exam. Based on this intuition, she decided to dramatically revamp the remainder of the fall semester. In place of the many of the scheduled lectures, she arranged field trips to local galleries and museums, where students could interact with the pieces and each other directly. This change was accepted enthusiastically by students, despite the logistical inconveniences and additional effort it entailed. As the semester drew to a close, she realized that she would always view her fall 2005 experience with particular fondness. All indications were that here students felt the same way.

\section{Spring Semester 2006}

In early December 2005, just as her fall course was winding down, Jeffrey needed to make some decisions about plans for the spring. Unfortunately, the success of the fall semester did little to make these decisions easier. The first question on her mind: Should the experiment be repeated? In making this decision, a number of new factors came into play. Although engaging in her fall experiment had taken a great deal of time- - time that was in short supply given her 6 course teaching load-the effort expended could, in part, be justified in terms of fulfilling her obligation to the ITI, which required all participants initiate at least one technology-based change to their fall semester classes. There was no such requirement for the spring semester, however. Instead, the ITI required participants to do something entirely different. The spring requirement was to set up a formal session with colleagues to inform them about the participant's fall experiences - which would be a further drain on her time.

Another concern she had about the spring related to the availability of the technology. As of 31 December 2005, the university's pilot testing arrangement would end. As of early December, there had been no 
indication — aside from some expressions of hope, tinged with desperation, from affected faculty members - that Elluminate would be available. The museum curator had already indicated a strong desire for a repeat performance. Not only was the experience fun, it also provided a museum with a unique way of fulfilling part of its outreach mission. How embarrassing would it be to schedule a session, then have to cancel it because there was no technology. If this transpired, would she ever be able to schedule another?

A final concern related to her confidence that the successful experience of the fall could be replicated. She heard already some expressions of surprise that things had gone so smoothly from various faculty Elluminate users. And, based on her own experiences dealing with the artistic community, she realized that she had hit the jackpot with her first round of guests. What would happen if the next group were less able to submerge their own egos to interact with students in a sensitive and meaningful way? She had such pleasant feelings when she recalled her first session. Was it worth taking the risk of jeopardizing these by offering another?

Even if she did decide to schedule another session, there were issues that needed to be resolved. One practical matter involved her schedule. While she had taught a single section of the course during the fall, in the spring semester she'd be teaching two-one at USF's main campus and one at USF's St. Petersburg campus. As a matter of fairness, she had always tried to make different sections of the same course completely equivalent. She didn't see how she could run the online session and museum visit for the St. Petersburg night section, however. There simply would not be time (and the museum would not be open during class time). Would it be fair to offer such a well-received activity to one group of students but not the other? And would there be resentment if they should happen to compare notes?

Another set of issues related to the time demands of organizing the session. The process of running practice sessions was very time consuming and frustrating - since students often chose not to show up. Despite this, she had been advised by colleagues that she would be better off conducting more, rather than fewer, of these sessions if she wanted to be safe. Even worse, arranging for student travel was very time consuming. If she had wanted to be in the travel business, she probably would have made that her career choice - not education and the arts. She wondered if there were any ways of making the whole process of training and logistics more efficient. Could technology play a role in reducing the demands that these placed upon her?

She also recognized that there were numerous technical issues that surfaced during the first session that were still unresolved. What do you do about students for whom purchasing a microphone is too great an investment? How do you handle students who need to use computers in the library or USF labs? Do you penalize a student whose technology worked during a practice session but failed during the actual class? She wondered if it were really prudent to proceed with so many unanswered questions.

As she pondered whether or not to set up a spring session, she felt a slight chill as she recalled the many nights during the fall when she was so keyed up about the upcoming session that she could not fall asleep. There were so many elements to bring together. It would be so easy to forget a crucial one. Counterbalancing this, however, was the sense of satisfaction she felt as she looked back upon the outcome. 


\section{Exhibit 1: Anne Jeffrey Biography}

\section{USF University of 5 School of Art and Art History}

\section{Anne Jeffrey}

Adjunct Professor: Art History

MA, University of South Florida, 2001

FAH 245

$813-974-9318$

ajeffrey@arts.usf.edu

Anne Jeffrey teaches on line courses: Introduction to Art, Art of the Western World and face to face courses: Contemporary Issues in Art, and Twentieth Century Art History (St. Petersburg Campus). She developed the department's first online course in 2004.

She received an Honor BA in Modern History from the University of Toronto, 1966 , and completed an MA in Art History, with a focus on contemporary art, at USF, 2001. Her career accomplishments include professional theater productions as a playwright in San Diego, Montreal and Vancouver; communications consultant and holding political office in British Columbia; publications such as "The Art Lovers' Guide to Florida", 1997, and art exhibition curating and catalogue writing in the state of Florida.

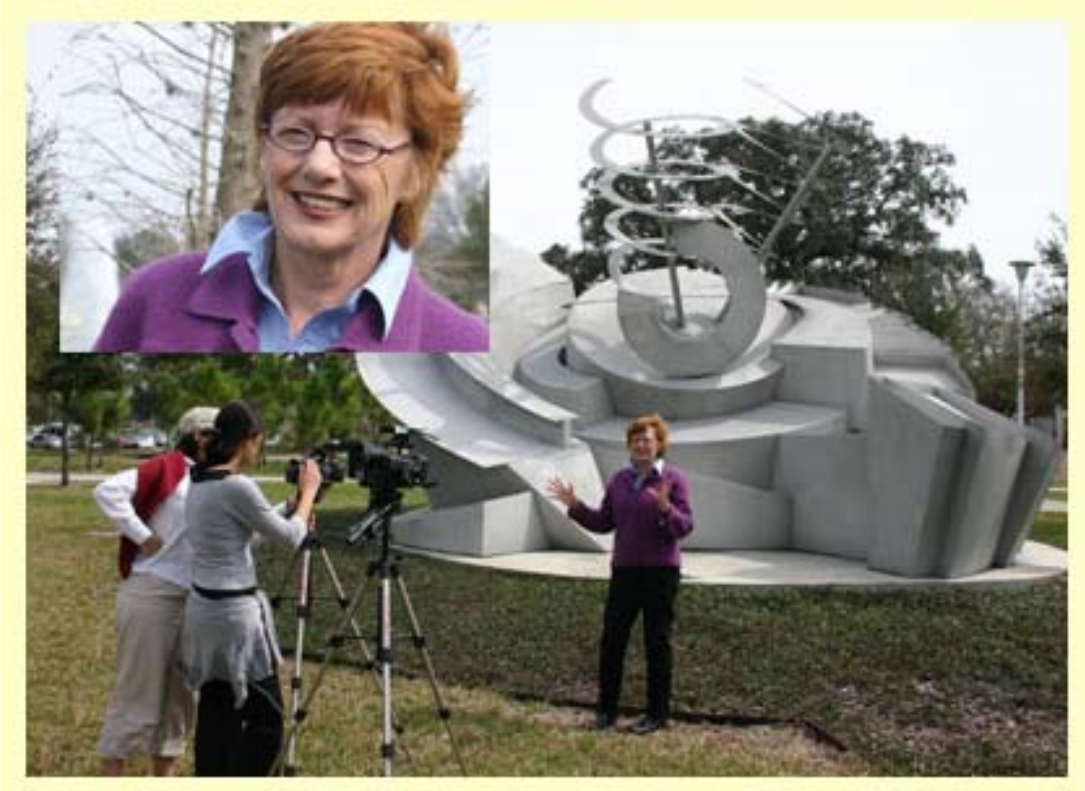

Source: http://www.art.usf.edu/fac/jeffrey.html accessed on 1/2/2006. 


\section{Exhibit 2: Elluminate Interface}

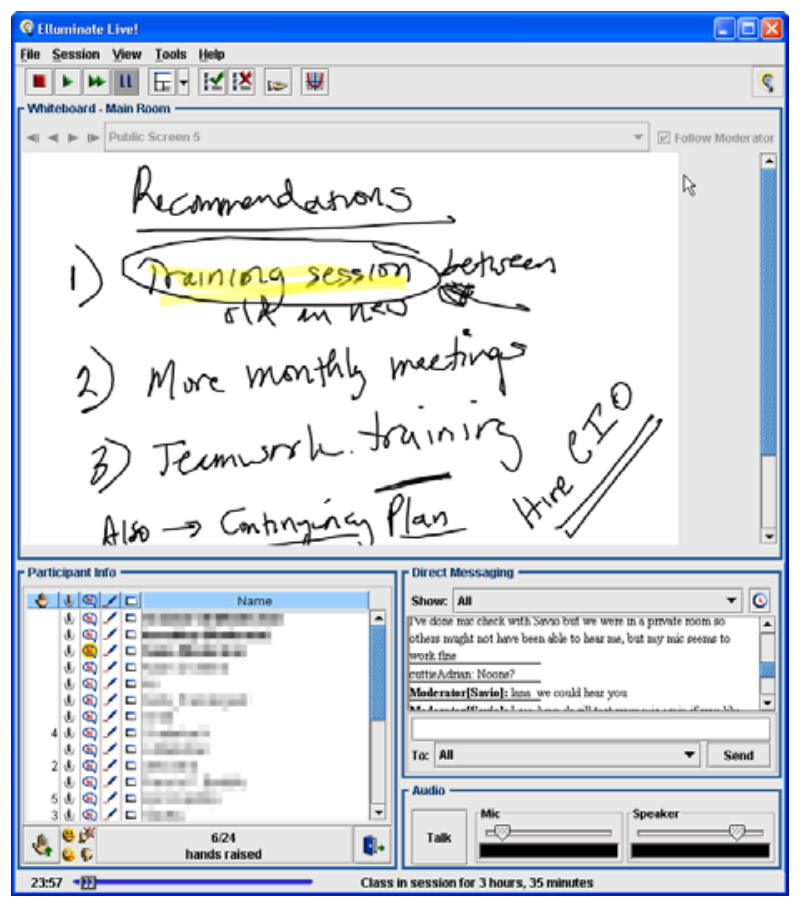

Case Discussion w/ shared whiteboard

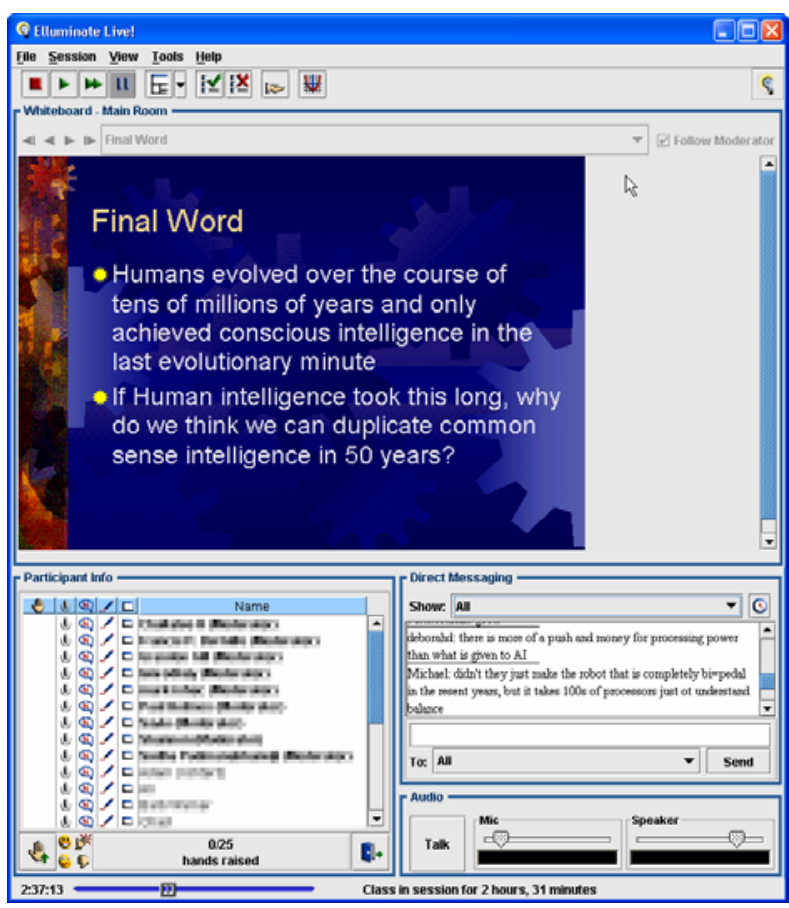

PowerPoint Slides 


\title{
Exhibit 3: Excerpts from Course Syllabus
}

\author{
CONTEMPORARY ISSUES IN ART
}

- What can you expect from this course? A high level of participation in discussions concerning the critical issues affecting art making practices during the latter part of the $20^{\text {th }}$ century and into the present. This means that development of your own critical thinking skills is a key component of this course.

- You will receive guidelines for class discussions and other assignments. My role as instructor is to provide clear discussion procedures, encourage individual students, and to generally create an optimal environment for the presentation of ideas and exchange of opinion. Your responsibility is to meet discussion requirements. This requires reading the background materials and developing questions and comments about the material. Participation is $20 \%$ of your final grade.

\section{What does active participation mean?}

$\begin{array}{ll}\checkmark & \text { Attentive during class } \\ \checkmark & \text { Being present and prepared for class discussions } \\ \checkmark & \text { Contributing to class discussion often! } \\ \checkmark & \text { Developing your own opinions } \\ \checkmark & \text { Encouraging diverse viewpoints }\end{array}$

- Whether you are participating as an individual or in a group, you will receive an individual grade. A midterm participation grade will be assessed for each student.

- In addition to selections from the required texts in this class, you will be responsible for the content of readings on electronic reserve.

- Your knowledge of factual material covered in this course ( the required texts, lectures, readings and instructor lectures) will be tested on a final exam (15\% of final grade) and in other assignments as outlined below.

- Assignments include student presentations, 2 brief response papers, 2 compare \& contrast exercises and a 7-8 page issues paper

- We will occasionally use an interactive software system called "ElluminateLive", as well as making use of Blackboard. You need a NET ID and password to access Blackboard. Academic Computing provides these for USF students. In class I will explain access and how we will uses "ElluminateLive".

- Learning Outcomes: Active participation in all course activities will increase your understanding and knowledge of processes and procedures used in contemporary art practices, sharpen your awareness of cultural production, and provide tools, such as vocabulary and elements of critical theory, to enhance your ability to undertake critical analysis of contemporary visual expression. 


\section{Grading criteria}

$\checkmark$ Class participation, 20\%. Your final grade will be based on your participation during my lectures, other students' presentations, and in online discussions

$\checkmark$ Ways of Seeing individual student presentation, 5\%

$\checkmark$ A 'featured artist' presentation, 10\%

$\checkmark$ On line discussions, 10\%

$\checkmark$ TMA 'talking points' paper 5\%

$\checkmark$ Public Art Dialogue 'talking points' paper, 5\%

$\checkmark$ Issues paper: $20 \%$

$\checkmark 2$ compare \& contrast exercises, $10 \%$

$\checkmark$ Final exam (cumulative) 15\%

\section{$\underline{\text { Other Resources }}$}

Blackboard:

We will be using our course shell from time to time. To access Bb you need a Net ID and USF email account. Frequently I will send emails to your USF email account via $\mathrm{Bb}$, so be sure to check your USF email account regularly!

Each of you has already received an email with an attachment explaining how to use the Discussion Board. Before our first class meeting I expect you to have contributed to the $\mathrm{Bb}$ discussion.

"Elluminate Live"

This is a new interactive software currently under license to USF. We have both a virtual classroom and I have a virtual office. If you do not have a headset with a mike, you need to purchase one.

\section{ASSIGNMENTS}

Ways of Seeing Presentation: group assignment, details will be available during the first class meeting. $5 \%$ of final grade.

Compare \& Contrast exercises; See class schedule for date. $10 \%$ final grade.

"Featured Artists" Presentations: You will select your artist the first day of class. See class schedule for the date you will present. Assignment details will be given in class. $10 \%$ of final grade.

Two 'talking points' papers: Developed and based on your attendance at two field trips. (Tampa Museum of Art and the Art in the Public Ream: A Dialogue)10\% of final grade.

\section{Issues Paper}

Guidelines will be distributed in class. Length: $7-8$ pages. $20 \%$ of final grade. Due Nov. 18 . NO EXCEPTIONS TO DUE DATE. Late papers automatically reduced by one letter grade.

\section{Final exam Dec. 9 (cumulative)}

Between 10-15 slide identifications: multiple choice, definitions, true and false questions, based on required texts, lectures, readings and class presentations. $15 \%$ of final grade. 


\section{$\checkmark$ Please note!}

Often you will view reproductions of work, in print, slide, DVD or video format which are considered by some people to be controversial due to the subject matter, materials and the real or perceived content.

The images shown in class will always be framed within the context of this course, i.e. the image is shown as a tool for understanding issues and current art practices. The image shown, in other words, is meant to demonstrate an issue under discussion --- such as censorship, for instance.

Images are not being presented as a form of titilation or as a spectacle for sensationalism. If you think you will not be comfortable viewing and discussing images of this nature (sometimes involving functions and activities of the human body), due to religious convictions and/or personal belief system it is recommended that you do not remain enrolled in this course.

\section{CLASS SCHEDULE [Excerpts relating to online session]}

Sept. $16 \mathrm{~F}$

Preparation for Elluminate Live discussion \& Gulf Coast Museum exhibition visit. Car pooling plans.

Sept. $23 \mathrm{~F}$

No class on USF campus.

$10 \mathrm{a}-11: 30 \mathrm{a} \ldots$ on line discussion on your home or campus PC. Headset required.

Fieldtrip: Gulf Coast Museum, Largo for

Florida Focus exhibition. Meet at Museum at 12:45 pm

$1-2$ page 'talking points' paper, typed prepared for '

Sept. 30

Sept. 30 F

Discussion: Florida Focus Exhibition

Lecture: Art History Refresher: the 1960s

Source: Fall 2005 course syllabus 


\section{Exhibit 4: Art Being Displayed During Online Session}

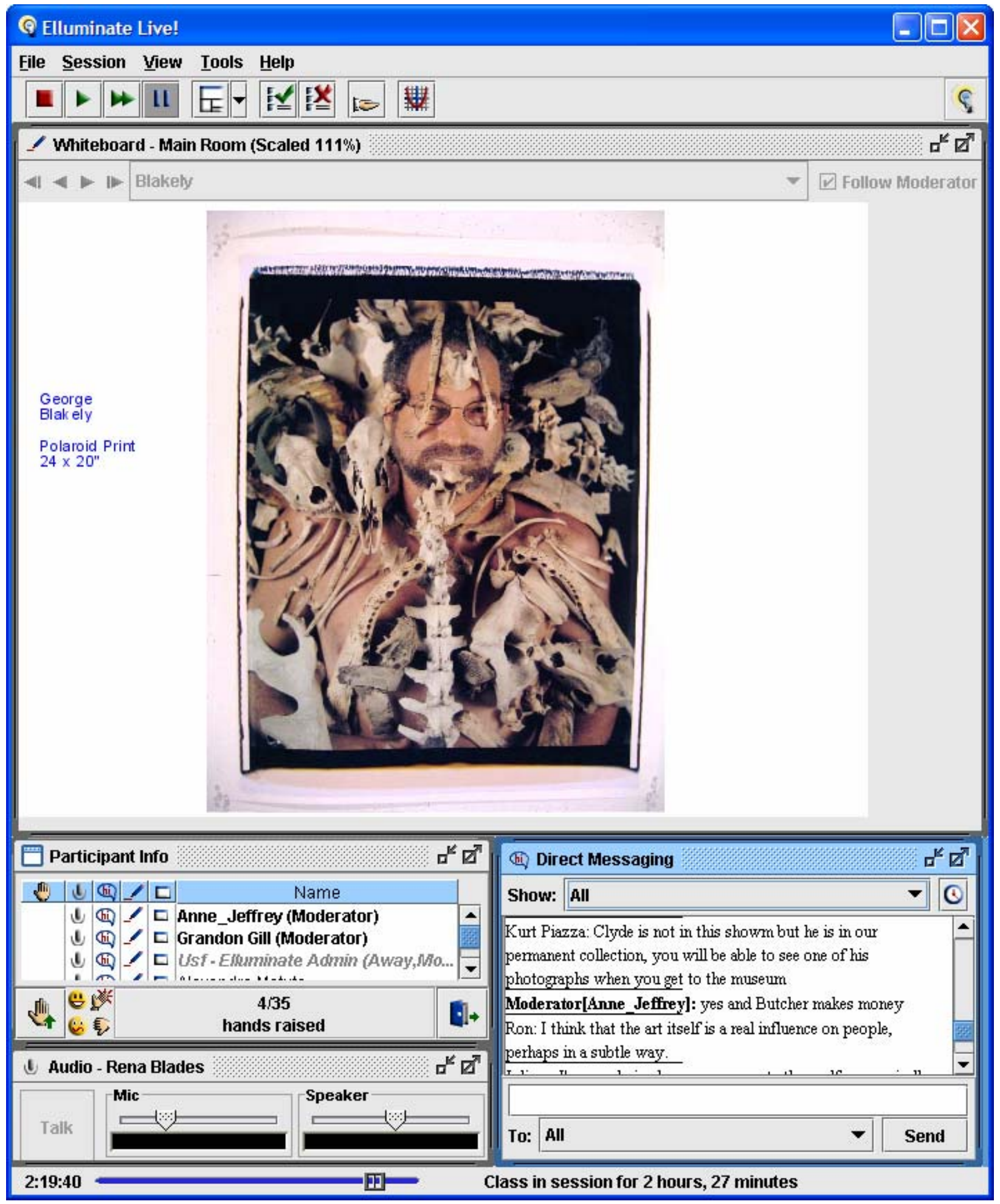




\section{Exhibit 5: Student Responses to Question about Online Session}

\section{Can an interactive session like the Elluminate Live example enhance an art viewing experience? How? Why? How could such a session work better?}

I think it helped the experience because with the discussion I actually noticed myself slowing down to catch all of the pieces and details that we talked about. The Elluminate Live was different than any other class discussion and I felt less anxious to ask questions. I felt more connected to the show more with the interactive session.

Yes...it gave me a "heads-up" of what to expect from the show, a perspective from the artists so I knew the ideas and "point" of their work. The only way I think it could work better is having more experience with "Elluminate Live!” which I know was not completely possible, but I think that the overall end product of my experience was beneficial.

I think it can. Relating with the artist really helps for the viewer to get a better understanding of what to expect and why. Knowledge of where the artist is coming from was to me the most important thing. It was great to hear everything you want to hear before you go because then it makes the viewing that much better. It could be better by viewing maybe multiple times because many may not have had a chance to associate with the artist. However it is a great system.

I think it offers me more potential distractions than enthusiast. If each person have their own image bank in addition to the communal image, than compare/contrast, and dialogue in general would be great, helpful. But one must always take into account the location of size and clarity.

I thought it did enhance my experience. I always love hearing from artists - talking about their process, experiences, influences, etc. and to have that information straight from the artist and it still be fresh in your mind while looking at the work was a great experience for me.

Having the Elluminate Live as a resource is a huge step. Being able to discuss things with the artist was amazing. This tool helped me to appreciate the actual work ten fold.

I think it did enhance the viewing. They all were very helpful with explaining the reasons for their art as wall as answering our questions. I thought knowing most came from North Florida or near North Florida was interesting and that there is a difference between the different regions. I thought it went very smoothly. I wouldn't have changed it.

I think the most important aspect was the discussion with the artists themselves, as well as those involved with the gallery. I hope that this program can become instituted permanently in the USF curriculum! It is very easy to use, as well as effective, for distance-learning. It was a good session before the actual event in person.

I think that it was a good introduction but I feel that it is hard to know what to speak about before actually viewing the work. It helped to go thinking about the concepts presented by the artists and curator. It may be more interesting to have the session after looking at the work. 
Yes, but I feel that art is best viewed in person. However, having an online discussion provides the needs to show art similarly to how it is viewed in class, but being online makes providing a good viewing experience more of a focus. Also, I think that being online makes it easier for people to give an honest opinion.

I felt the on-line experience would have been more helpful is we had studied some of their previous works before and their biography. I felt that I could have asked better questions if I have been more knowledgeable. I enjoyed talking to the artists before seeing their work. It was like an appetizer before dinner.

It can enhance this type of experience because you get a background about the exhibition and an idea of where the artists are coming from with their works; before you see the exhibit. A session like this could work better if there was a way to make sure the audio was working throughout the entire session.

Could be better by making sure everyone gets online a half hour sooner so they'd be sure everything worked properly, also finding a way to make the sound breaks stop over the headphones.

It works really well. Being able to talk with the artists, curators, etc. regardless of schedules or geography is amazing. The insight they are able to give is extremely beneficial to the viewing of the work. I think that Elluminate Live worked pretty well. Maybe just working out the kinks, like microphones working or more visual aids to go with the discussions, will help out.

I think it can really enhance the viewer's experience. For example with Robert Blakely's piece we learned that it is not historical, but speaks on what we leave behind, something that would have been difficult to pick upon. Also, learning the curators purpose, goals, etc. was very helpful as well, for example we discussed the shows emphasis on North Florida and rather than South Florida art. To hear directly from the behind-the-scenes people (curator and artists) made the experience more in-depth and educational. I think, as discussed that giving the students reading material, going to the show and then having the discussion would have been more in depth because we would have had a better understanding of the art and would have had the possibility to ask different questions.

I thought that the interaction before viewing the art was somewhat helpful, because we are able to get the point of view of the artist and those that help these artists, but without the gallery card that describes the artist and work. Maybe the live class could be better if it was longer or a visual of the main person(s) talking.

The opportunity to talk with the artists and curators gave an interesting aspect to the experience. More time.

In a way interactive session like the one that we had last Friday on Elluminate can and cannot enhance an art viewing experience. For one reason that it was is that you can talk to important 
people that are out there live at anytime. Instead of waiting till the time that you will be able to meet. For the reason it might is the simple fact that people don't like to be on the computer.

I think the Elluminate Live session was fun and I do believe it did enhance the art viewing experience. I felt like I knew the artists that we spoke with personally, and that I had a deeper understanding of their works. When I got to the museum I immediately wanted to find their art pieces. I think it should be mandatory to require students to have questions, it makes you pay attention. Otherwise it would be very easy to become distracted if you are at home, like I was. I think it would be wise to have a mandatory practice session for everyone to attend before the actual session.

The Elluminate Live session that we have before our trip to the Gulf Coast Museum of Art did enhance the overall experience of going to the exhibition. It enabled you to get more information of what the show and all the artists were about before your arrival making it a little more exciting. I think that the session went pretty smoothly. Although seeing the images over the internet did help you get a general idea of what the work depicted. Reproductions can sometimes give you a completely different idea of what the actual work looks like. For example Lillian Garcia Roig's work looked almost photoreal when it was viewed online but when it is seen in real life the abstract qualities of the work come out more.

I think it can definitely be great in art educational context. Exactly the way it was done for us in class. We had an opportunity to talk to the artists together as a class - very interesting experience.

It certainly helps to be able to talk to the artists directly, exactly as if they were addressing each student individually. As for working better, it would be better if the procedure was less involved; I don't have much of a memory for complicated maneuvers.

The Elluminate Live session was very successful indeed in terms of understanding the exhibition as a whole and seeing a different perspective of those who put the event together. It is like the difference of going to Blockbuster and renting a video based solely by the summary on the back of the case or renting a movie after seeing the previews and chatting with the cast/crew. The software gives students a chance to get to know the artists and their work in a more personal way; rather than looking over some pamphlet of an exhibition. On a technical aspect, I would have liked more time to have questions answered. I was a bit discouraged that I was never called on! In addition, it would have been more stimulating if everyone had a webcam. Moreover, the session was new, different, and I loved the fact that I could have class from the comfort of my own home. If I were you, I would encourage your fellow faculty members to use this media more often for their classes as well.

I don't think that Elluminate can enhance an art “viewing” experience directly, i.e. it would not be effective to show artworks on the screen by themselves alone. As it was used last Friday, however, it was an effective preparation for viewing the art. The only thing that would be better would be to be able to talk to the artists while viewing the art and have them explain their own work in person. To explain this I will give an example. The work of Lillian Garcia-Roig was uninspiring, by itself in pictures on the screen (or the brochure for that matter). The opportunity 
to hear her talk about her work made it much more appealing, encouraging me to make sure that I looked closely at it when I went to the museum. Once at the museum, I was in for a pleasant surprise. Though it was mentioned in the discussion that the painting were large, that was not the best part. The painting itself was delicious with heavy impasto. The impasto and her choice of dense subject matter do not photograph well at all. Mark Messersmith's work was similarly enhanced by hearing the artist talk about his process and intent, thought not as dramatically as for Lillian's.

The session would be more effective with more artists describing their work. I think the format worked pretty well with the questions stimulating the artists to explain their work, though live video would be even better. This would be difficult to do and require much wider bandwidth and better, more expensive equipment not easily available, so is not practical. A smaller group of students would certainly be more effective. A larger screen would be better, but this depends on the equipment that each student has available. It was difficult to see all the pertinent information, like who was raising their hand, etc. The message feature became distracting and I largely ignored it with the large group. The ability to move the sub windows around was important, though I think most folks had their formats locked. In the end, I think the only big failing was that the group was too large. 


\section{Biographies}

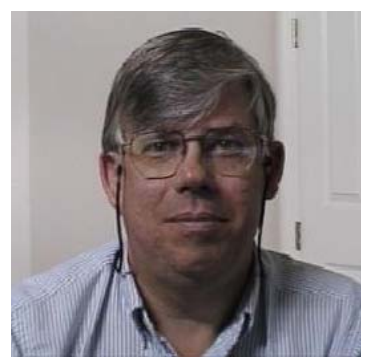

Grandon Gill is an Associate Professor in the Information Systems and Decision Sciences department at the University of South Florida. He holds a doctorate in Management Information Systems from Harvard Business School, where he also received his M.B.A. His principal research focus is in the area of IS education, and he has published many articles describing how technologies and innovative pedagogies can be combined to increase the effectiveness of teaching across a broad range of IS topics. Currently, he teaches programming, database and managerial courses to both undergraduate and graduate students.

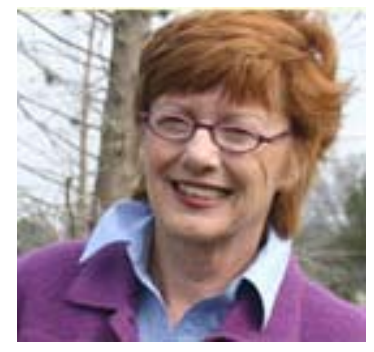

Anne Jeffrey is an Adjunct Professor of Art History at the University of South Florida. She received her MA in Art History in 2001, with a focus on issues in Contemporary Art. Her first teaching assignments at USF included a face to face course: Introduction to Art. Jeffrey initiated and developed this class into an entirely web based course, through collaboration with the Media Innovation Team at USF. Since living in Florida she co-authored "The Art Lovers' Guide to Florida", and has written exhibition catalogues for the St. Petersburg Museum of Fine Arts. She frequently teaches art history courses in Paris for the USF Paris Art Program. 